\title{
PENGARUH PEMBERIAN SEDUHAN DAUN KELOR (MORINGA OLEIFERA LAMK) TERHADAP KADAR ASAM URAT TIKUS PUTIH (Rattus norvegicus)
}

\author{
Rahmawati, Aryu Candra $\mathbf{K}^{*}$ \\ Program Studi Ilmu Gizi Fakultas Kedokteran Universitas Diponegoro \\ Jl.Dr.Sutomo No.18, Semarang, Telp (024) 8453708, Email : gizifk@ undip.ac.id
}

\begin{abstract}
Background: Uric acid is the end product of purine metabolism. If the serum uric acid has an excessive level, it can induce many diseases, such as gout. Moringa oleifera Lamk, known as "daun kelor" in Indonesia, has been used as a herb medicine for the treatment of gout, arthritis and other diseases because its phytochemical contains. The present of study was carried out to investigate the effect of moringa leaves infusion on serum uric acid in rats.

Methods : Twelve Wistar rats with body weight of 150 - $180 \mathrm{~g}$ were grouped equally into two groups randomly. They were orally administered goat brain $2 \mathrm{~g} / \mathrm{rat} /$ day for 8 days. After being given goat brain, control and treatment group were given aquades and moringa leaves infusion 3,6 $\mathrm{ml}$ for 14 days, respectively. Moringa leaves powder dose 3,75 $\mathrm{g} / \mathrm{kg}$ bw was steeped with hot water $\left(60^{\circ} \mathrm{C}\right)$. The normality of datas were tested with Saphiro-Wilk, then analyze by dependent pair t test. To analyze the different between both groups, they were analyzed with independent pair t test.

Results : The changing of serum uric acid before and after being given goat brain in control and treatment group each groups are $-0,529 \mathrm{mg} / \mathrm{dl}(p=0,002)$ and $0,831 \mathrm{mg} / \mathrm{dl}(p=0,04)$, respectively. The changing of serum uric acid before and after being given moringa leaves infusion in treatment group is 0,675 $\mathrm{mg} / \mathrm{dl}(\mathrm{p}=0,04)$.
\end{abstract}

Conclusion : Moringa leaves infusion doses 3,75 $\mathrm{g} / \mathrm{kgbw}$ can reduce serum uric acid in rats after 14 days.

Keyword : uric acid serum, moringa leaves, antioxidant, flavonoid

\begin{abstract}
ABSTRAK
Latar belakang : Asam urat merupakan hasil akhir metabolisme purin yang apabila dalam jumlah yang berlebihan dapat memicu terjadinya berbagai macam penyakit, salah satunya adalah gout. Moringa oleifera lamk, atau dikenal dengan daun kelor telah dipercaya masyarakat sebagai tanaman herbal untuk gout, arthritis, dan beberapa penyakit lainnya karena kandungan fitokimianya. Penelitian ini bertujuan untuk mengkaji pengaruh pemberian seduhan daun kelor (Moringa oleifera Lamk) terhadap kadar asam urat tikus putih.

Metode : Dua belas ekor tikus wistar jantan dengan berat 150 - 180 g dibagi menjadi dua kelompok secara acak. Kedua kelompok diberi otak kambing 2 g/ekor/hari selama 8 hari. Selanjutnya, kelompok kontrol (K) diberi akuades, sedangkan pada kelompok perlakuan $(P)$ diberi seduhan daun kelor 3,6 ml selama 14 hari. Bubuk daun kelor dengan dosis $3,75 \mathrm{~g} / \mathrm{kg}$ berat badan diseduh dengan air hangat bersuhu $60^{\circ} \mathrm{C}$. Data yang diperoleh diuji normalitasnya menggunakan Saphiro-Wilk. Perbedaan kadar asam urat sebelum dan sesudah perlakuan pada masing - masing kelompok diuji dengan dependent pair t test. Untuk mengetahui perbedaan antara kedua kelompok digunakan uji
\end{abstract} independent pair t test.

Hasil penelitian : Perubahan kadar asam urat sebelum dan sesudah pemberian otak kambing pada kelompok kontrol dan perlakuan adalah $-0,529 \mathrm{mg} / \mathrm{dl}(p=0,002)$ dan 0,831 $\mathrm{mg} / \mathrm{dl}(p=0,08)$. Perubahan kadar asam urat sebelum dan sesudah pemberian seduhan daun kelor pada kelompok perlakuan adalah 0,675 $\mathrm{mg} / \mathrm{dl}(\mathrm{p}=0,04)$.

Kesimpulan : Pemberian seduhan daun kelor dengan dosis 3,75 g/kgbb selama 14 hari dapat menurunkan kadar asam urat tikus.

Kata kunci : kadar asam urat, daun kelor, antioksidan, flavonoid

\section{PENDAHULUAN}

Asam urat merupakan produk akhir metabolisme purin yang kemudian dikeluarkan melalui urin, feses, dan keringat. ${ }^{1}$ Asam urat dapat berperan sebagai antioksidan atau pro - oksidan. ${ }^{2}$ Dalam keadaan normal, asam urat berperan sebagai antioksidan. ${ }^{3}$ Akan tetapi, kadar asam urat yang berlebihan (hiperurisemia) dapat beralih menjadi oksidan kuat, serta menyebabkan terjadinya endapan asam urat di sendi yang akan menimbulkan peradangan sendi (gout). ${ }^{2}$ Peningkatan kadar asam urat diduga erat kaitannya dengan peningkatan risiko hipertensi, penyakit kardiovaskular, dan penyakit ginjal kronis. Selain itu, peningkatan kadar asam urat merupakan salah satu faktor risiko penyakit arteri periferal, resisten insulin, dan sindrom metabolik. ${ }^{2,4}$

Hiperurisemia terjadi akibat peningkatan produksi asam urat atau penurunan eksresi urat atau merupakan gabungan keduanya. Hiperurisemia akibat peningkatan produksi asam urat jarang terjadi pada pasien hiperurisemia. Kejadian tersebut dapat terjadi akibat diet tinggi purin atau pemecahan asam nukleat yang berlebihan akibat penyakit tertentu seperti gangguan genetik, limfoma, dan tumor yang memicu terjadi pembelahan sel berlebih. ${ }^{1,5} \mathrm{Di}$ 
samping diet tinggi purin, konsumsi diet tinggi fruktosa juga dapat meningkatkan risiko terjadinya hiperurisemia melalui peningkatan katabolisme adenin nukleotida. ${ }^{5,6}$

Sintesis asam urat dapat dihambat dengan berbagai cara, di antaranya dengan diit rendah purin dan fruktosa, terapi medik, atau menggunakan tanaman herbal seperti daun kelor. Daun kelor memiliki kandungan senyawa antioksidan seperti flavonoid, vitamin C, dan vitamin E. ${ }^{7}$ Senyawa senyawa tersebut diketahui mampu menurunkan kadar asam urat dalam darah dengan berperan sebagai antioksidan yaitu peredam (scavenger) radikal bebas. ${ }^{8}$ Jenis flavonoid seperti kuersetin dan kaempferol dapat menghambat kinerja xanthine oxidase dan xanthine dehydrogenase, sehingga dapat menghambat sintesis asam urat. ${ }^{9}$ Asupan vitamin $\mathrm{C}$ yang cukup diduga dapat mencegah terjadinya hiperurisemia dan perkembangannya lebih lanjut seperti gout dan nefropati hiperurisemia. ${ }^{10,11}$ Kandungan vitamin $C$ daun kelor lebih tinggi tujuh kali lipat dari jeruk. ${ }^{12}$

Tanaman Kelor (Moringa oleifera Lamk) merupakan jenis tanaman yang banyak dijumpai di Indonesia, tidak mengenal musim, dapat tumbuh dalam berbagai iklim dan di beberapa daerah biasa diolah untuk dikonsumsi. Tanaman ini dipercaya mampu menyembuhkan berbagai penyakit, di antaranya ekstrak daun kelor diketahui mampu menjadi antioksidan ${ }^{13,14,15}$, hepatopreotective ${ }^{14}$, imunomodulator ${ }^{16}$, dan antiinflamasi ${ }^{17,18}$. Ekstrak daun kelor terbukti memiliki sifat antioksidan dan hepatoprotective dengan memperbaiki membran sel hepar pada tikus yang diberi paparan Carbon Tetrachloride $\left(\mathrm{CCl}_{4)} \cdot{ }^{14}\right.$ Beberapa penelitian sebelumnya menunjukan bahwa pemberian ekstrak maupun bubuk daun kelor dapat menurunkan kadar asam urat pada tikus putih jantan galur wistar. ${ }^{16,18,19}$ Pemberian teh daun kelor selama 7 hari menunjukan aktivitas antiinflamasi pada radang paru-paru akut pada tikus. $^{20}$

Penelitian lain melaporkan bahwa terdapat penurunan kadar asam urat dengan pemberian kuersetin dosis $5 \mathrm{mg} / \mathrm{kg}$ berat badan pada tikus wistar hiperurisemia selama 14 hari. ${ }^{21}$ Dalam penelitian ini, untuk melihat pengaruh daun kelor yang lebih signifikan, maka dosis kuersetin yang digunakan sebagai acuan dua kali lipat dosis sebelumnya yaitu $10 \mathrm{mg} / \mathrm{kg}$ berat badan. Kuersetin $10 \mathrm{mg} / \mathrm{kg}$ berat badan dapat diperoleh dari $11,1 \mathrm{~g}$ daun kelor segar. Kuersetin merupakan salah satu jenis flavonoid yang paling banyak ditemukan dalam daun kelor yaitu sebesar 89,9 mg/100 g daun segar. ${ }^{22}$ Kandungan kuersetin daun kelor lebih tinggi dibandingkan bawang merah (Allium cepa L.) yaitu hanya sebesar $284-486 \mathrm{mg} / \mathrm{kg} .{ }^{23}$ Berdasarkan penelitian sebelumnya, bawang merah memiliki aktivitas hipouremik sehingga mampu menurunkan kadar asam urat pada tikus hiperurisemia. ${ }^{21}$

Olahan daun kelor dapat ditemukan dalam bentuk ekstrak, bubuk, dan teh. Produk - produk tersebut bertujuan untuk mempermudah penggunaanya di masyarakat, serta meningkatkan masa simpan. Akan tetapi, belum terdapat penelitian ilmiah mengenai pengaruh konsumsi seduhan daun kelor terhadap penurunan kadar asam urat dengan subjek hewan coba maupun manusia. Oleh karena itu, penelitian ini diawali dengan menggunakan hewan coba. Pemilihan hewan coba adalah tikus galur wistar karena tahan terhadap perlakuan pada penelitian. Berdasarkan penelitian pendahuluan, dosis yang digunakan adalah $3,75 \mathrm{~g} / \mathrm{kg}$ berat badan bubuk daun kelor yang diperoleh dari $11,1 \mathrm{~g}$ daun kelor segar.

\section{METODE PENELITIAN}

Penelitian ini menggunakan metode true experimental dengan rancangan pre and post test randomized control group design. Variabel bebas pada penelitian ini adalah pemberian seduhan daun kelor, sedangkan variabel terikat dalan penelitian ini adalah kadar asam urat. Penelitian dilakukan di Laboratorium Biologi FMIPA Universitas Negeri Semarang.

Subjek penelitian yang digunakan adalah tikus jantan galur wistar usia $2-3$ bulan dengan berat badan rata - rata 150 - 180 gram yang diperoleh dari Laboratorium Biologi FMIPA Universitas Negeri Semarang. Jumlah subjek yang digunakan berdasarkan ketentuan WHO dengan jumlah sampel minimal 5 ekor. Dengan mempertimbangkan faktor risiko drop out sebesar 10\% maka ditambah 1 ekor tikus dalam setiap kelompok, sehingga diperoleh jumlah sampel per kelompok sebanyak 6 ekor. Jadi, jumlah sampel dalam penelitian ini adalah 12 ekor tikus yang terbagi menjadi 2 kelompok. Seluruh subjek terlebih dahulu diaklimatisasi selama 7 hari dengan diberi pakan standar sebanyak 20 gram/ ekor/ hari.

Selanjutnya subjek dibagi menjadi dua kelompok secara acak yaitu kelompok kontrol dan kelompok perlakuan. Kedua kelompok diberi pakan standar dan otak kambing selama 8 hari. ${ }^{24}$ Pada tahap intervensi, kelompok kontrol diberi pakan standar dan akuades, sedangkan kelompok perlakuan diberi pakan standar dan seduhan daun kelor dengan dosis $3,75 \mathrm{~g} / \mathrm{kg}$ berat badan bubuk daun kelor selama 14 hari.

Pembuatan seduhan daun kelor diperoleh dari $3,75 \mathrm{gram} / \mathrm{kg}$ berat badan yang diseduh dengan 
3,6 $\mathrm{ml}$ air hangat. Dosis bubuk daun kelor sebesar $3,75 \mathrm{~g} / \mathrm{kgbb}$ diperoleh dari $11,1 \mathrm{~g}$ daun kelor segar. Penentuan dosis diperoleh dari konversi dosis kuersetin sebesar $10 \mathrm{mg} / \mathrm{kg}$ berat badan tikus. Cara pembuatan bubuk daun kelor seperti penelitian sebelumnya yaitu dengan mengeringkan $11,1 \mathrm{~g}$ daun kelor segar, selanjutnya dihaluskan dengan menggunakan grinder. Proses pengeringan dilakukan di tempat teduh dan bebas serangga, hewan pengerat, serta debu. ${ }^{25}$ Pemberian otak kambing dan seduhan dilakukan dengan sonde.

Pengambilan darah subjek dilakukan tiga kali yaitu sebelum diberi induksi, setelah diinduksi, dan setelah diberi intervensi. Sampel darah diambil sebanyak 1,5 ml melalui plexus retroorbitalis dan dimasukkan ke dalam tabung hematokrit, kemudian darah disentrifus untuk mendapatkan serumnya. Kadar asam urat ditentukan dengan metode enzymatic photometric test TBHBA (2,4,6 tribromo - 3 - hydroxybenzoic acid).

Data yang diperoleh diolah dengan proram komputer. Data yang telah ada, diuji normalitasnya dengan uji Shapiro-Wilk karena $\mathrm{n}<50$. Perbedaan

kadar asam urat sebelum dan sesudah perlakuan masing - masing kelompok diuji dengan dependent pair t-test karena data berdistribusi normal Untuk melihat perbedaan antara kelompok kontrol dengan perlakuan digunakan uji independent $t$ test.

\section{HASIL PENELITIAN}

Penelitian mengenai pengaruh pemberian seduhan daun kelor (Moringa oleifera Lamk) terhadap kadar asam urat tikus putih (Rattus norvegicus) telah dilakukan. Sebanyak 12 ekor tikus telah dilakukan analisis kadar asam urat dengan metode enzymatic photometric test TBHBA $(2,4,6-$ tribromo - 3 - hydroxybenzoic acid). Data sebelum dan setelah diberi otak kambing, serta setelah diberi seduhan daun kelor yang telah didapat, diuji normalitasnya menggunakan uji Shapiro-wilk karena sampel kurang dari 50. Berdasarkan uji Saphiro-wilk, seluruh data berdistribusi normal ( $\mathrm{p}>$ $0,05)$

Perubahan Kadar Asam Urat Sebelum dan

\section{Sesudah Pemberian Otak Kambing}

Tabel 1. Rata-Rata Kadar Asam Urat Sebelum dan Sesudah Pemberian Otak Kambing

\begin{tabular}{cccccc}
\hline Kelompok & $\mathbf{n}$ & $\begin{array}{c}\text { Sebelum } \\
(\mathbf{m g} / \mathbf{d l} \pm \text { SD) }\end{array}$ & $\begin{array}{c}\text { Sesudah } \\
(\mathbf{m g} / \mathbf{d l} \pm \text { SD })\end{array}$ & $\begin{array}{c}\Delta \\
(\mathbf{m g} / \mathbf{d l} \pm \text { SD })\end{array}$ & $\boldsymbol{p}$ \\
\hline Kontrol & 6 & $3,488 \pm 0,387$ & $2,959 \pm 0,545$ & $-0,529 \pm 0,226$ & $0,002 *$ \\
\hline Perlakuan & 6 & $1,632 \pm 0,568$ & $2,463 \pm 0,474$ & $0,831 \pm 0,954$ & 0,08 \\
\hline
\end{tabular}

*beda bermakna $(p<0,05)$

Tabel di atas menunjukkan adanya perbedaan perubahan rerata kadar asam urat sebelum dan sesudah pemberian otak kambing. Pada kelompok perlakuan terjadi peningkatan rerata kadar asam urat sebesar $0,831 \mathrm{mg} / \mathrm{dl}$, akan tetapi tidak signifikan secara statistik $(p=0,08)$. Sedangkan pada kelompok kontrol terjadi penurunan rerata kadar asam urat yang signifikan yaitu $0,529 \mathrm{mg} / \mathrm{dl}(p=0,002)$ setelah pemberian otak kambing. Dengan demikian, menunjukkan bahwa penggunaan otak kambing sebagai induksi tidak dapat meningkatkan kadar asam urat secara signifikan.

Perubahan Kadar Asam Urat Sebelum dan Sesudah Pemberian Seduhan Daun Kelor

Tabel 2. Rata-Rata Kadar Asam Urat Sebelum dan Sesudah Diberi Seduhan Daun Kelor

\begin{tabular}{cccccc}
\hline Kelompok & $\mathbf{n}$ & $\begin{array}{c}\text { Sebelum } \\
(\mathbf{m g} / \mathbf{d l} \pm \text { SD) }\end{array}$ & $\begin{array}{c}\text { Sesudah } \\
(\mathbf{m g} / \mathbf{d l} \pm \text { SD) }\end{array}$ & $\begin{array}{c}\Delta \\
(\mathbf{m g} / \mathbf{d l} \pm \text { SD })\end{array}$ & $\boldsymbol{p}$ \\
\hline Kontrol & 6 & $2,959 \pm 0,545$ & $2,411 \pm 0,454$ & $0,548 \pm 0,744$ & 0,13 \\
\hline Perlakuan & 6 & $2,463 \pm 0,474$ & $1,788 \pm 0,185$ & $0,675 \pm 0,606$ & $0,04 *$ \\
\hline
\end{tabular}

*beda bermakna $(p<0,05)$

Pada tabel 2 menunjukkan adanya penurunan rerata kadar asam urat pada kedua kelompok. Rerata penurunan kelompok kontrol sebesar $0,548 \mathrm{mg} / \mathrm{dl} \quad(p=0,13)$. Sedangkan pada kelompok perlakuan hanya mengalami penurunan sebesar $0,675 \mathrm{mg} / \mathrm{dl} \quad(p=0,04)$. Maka dapat disimpulkan bahwa pada kelompok perlakuan yang diberi seduhan daun kelor terdapat penurunan yang signifikan dibandingkan dengan kelompok kontrol.

Berdasarkan uji beda yang dilakukan antara kedua kelompok setelah diberi seduhan daun kelor diperoleh $p$ sebesar $0,12 \quad(p>0,05)$ yang 
menunjukkan tidak terdapat perbedaan yang bermakna.

\section{PEMBAHASAN}

Dalam penelitian ini 12 ekor tikus galur wistar dibagi menjadi dua kelompok yaitu kelompok kontrol (K) dan kelompok perlakuan (P) yang masing - masing kelompok terdiri dari 6 ekor. Sebelum diberi perlakuan, seluruh subjek diadaptasikan selama 7 hari dengan diberi pakan standar yaitu BR2. Untuk meningkatkan kadar asam urat tikus, pada masing - masing kelompok diberi pakan tinggi purin yaitu otak kambing sebanyak 2 g/ekor selama 8 hari. Pada hari selanjutnya, kelompok perlakuan mulai diberi seduhan daun kelor, sedangkan kelompok kontrol hanya diberi akuades. Pemberian otak kambing dan seduhan daun kelor diberikan melalui sonde. Pemberian intervensi dilakukan selama 14 hari dengan dosis daun kelor sebanyak $3,75 \mathrm{~g} / \mathrm{kg}$ berat badan tikus dalam 3,6 ml air hangat.

Pemberian otak kambing sebanyak 2 g/ekor selama 8 hari tidak dapat meningkatkan kadar asam urat secara signifikan atau mencapai kondisi hiperurisemia $(>7,5 \mathrm{mg} / \mathrm{dl})^{26}$. Berdasarkan tabel 1, kadar asam urat tikus pada kelompok perlakuan mengalami peningkatan sebesar 0,831 $\mathrm{mg} / \mathrm{dl}$ setelah diberi otak kambing $(\mathrm{p}=0,08)$. Hasil ini bertentangan dengan penelitian sebelumnya yang menyatakan bahwa dengan pemberian otak kambing sebanyak 2 g/ekor/hari dapat meningkatkan kadar asam urat tikus secara signifikan. ${ }^{24}$ Hal ini diduga akibat perbedaan penyajian otak kambing yang diberikan.

Pada penelitian ini, otak kambing dimasak terlebih dahulu dengan cara pengukusan. Proses pemasakan diketahui dapat menurunkan kandungan purin yang terdapat dalam makanan. ${ }^{27}$ Sedangkan pada penelitian sebelumnya tidak dijelaskan bagaimana cara penyajian otak kambing yang diberikan. Selain itu, adanya enzim urikase pada tikus diduga turut mempengaruhi lambatnya peningkatan kadar asam urat. Enzim urikase berperan mengubah asam urat menjadi alantoin, di mana alantoin lebih mudah diekskresikan dibanding asam urat. Jika enzim urikase belum dihambat secara optimal, maka asam urat akan terus diubah menjadi alantoin. Dengan demikian, kadar asam urat akan turun. ${ }^{28}$

Jika pada kelompok perlakuan mengalami peningkatan, hal ini berbanding terbalik dengan kelompok kontrol. Pada kelompok kontrol mengalami penurunan kadar asam urat sebesar $0,529 \mathrm{mg} / \mathrm{dl}$ dari $3,488 \mathrm{mg} / \mathrm{dl}$ menjadi $2,959 \mathrm{mg} / \mathrm{dl}$. Hal ini bisa disebabkan karena adanya enzim urikase dalam tubuh tikus yang dapat mengubah asam urat menjadi alantoin, di mana alantoin lebih mudah diekskresikan. ${ }^{28}$ Berdasarkan tabel 1 , nilai signifikansi rerata kadar asam urat sebelum diberi otak kambing adalah $0,000(\mathrm{p}<0,05)$, yang berarti beda bermakna. Sedangkan setelah pemberian otak kambing tidak beda bermakna $(\mathrm{p}=0,12)$. Oleh karena itu, diduga adanya faktor lain yang mempengaruhi hasil pemeriksaan kadar asam urat sebelum diberi otak kambing pada kelompok kontrol.

Faktor - faktor yang diduga mempengaruhi penurunan kadar asam urat tersebut diantaranya adanya perbedaan yang terdapat pada obyek yang diukur, perbedaan situasi pada saat pengukuran, perbedaan alat dan instrumentasi yang digunakan, dan perbedaan pembacaan hasil pengukuran. ${ }^{29}$ Salah satu faktor perbedaan antara obyek yang diukur adalah berat badan. Jika dilihat secara statistik, tidak ada perbedaan yang bermakna antara kedua kelompok $(p=0,54)$. Setelah dianalisis dengan menggunakan uji regresi linear, variabel berat badan tidak berpengaruh terhadap kadar asam urat tikus sebelum diberi otak kambing, dengan nilai signifikansi sebesar 0,813 ( $p>0,05)$.

Faktor lain seperti usia, jenis kelamin, dan hormon diduga tidak berpengaruh pada perbedaan kadar asam urat kedua kelompok tersebut. Jika dilihat dari faktor usia, rata - rata usia subjek sama yaitu $2-3$ bulan. Faktor jenis kelamin dan hormon diduga juga tidak berpengaruh pada perbedaan kadar asam urat antara kedua kelompok. Sebuah penelitian melaporkan bahwa hormon estrogen dan androgen tidak berpengaruh pada sintesis purin. Namun, berbeda dengan hormon progesteron yang secara signifikan dapat menurunkan kadar asam urat pada tikus. ${ }^{30}$ Hormon progesteron dapat ditemukan pada tikus betina, sedangkan pada penelitian ini, subjek yang digunakan berjenis kelamin jantan. Dengan demikian, tidak terdapat hubungan antara usia, jenis kelamin, dan hormon terhadap perbedaan kadar asam urat pada kedua kelompok.

Faktor lain yang diduga juga berperngaruh terhadap hasil pemeriksaan kadar asam urat adalah perbedaan alat dan instrumentasi yang digunakan, di antaranya jumlah bahan pemeriksaan serum ${ }^{31}$ dan reagen ${ }^{32}$. Jumlah serum yang digunakan sebagai bahan pemeriksaan tidak diketahui oleh peneliti. Dilihat berdasarkan prosedur pemeriksaan, jumlah sampel yang dibutuhkan adalah $20 \mu 1 .{ }^{32}$ Sedangkan dilihat dari faktor reagen, hasil pemeriksaan kadar asam urat dengan menggunakan reagen uric acid FS*TBHBA dapat dipengaruhi oleh asam askorbat meski hanya dalam konsentrasi yang sedikit dan hemoglobin dengan kadar 100 mg/dl. Akan tetapi, 
dalam penelitian ini tidak dilakukan pemeriksaan kadar asam askorbat dan hemoglobin, sehingga tidak diketahui apakah kedua faktor tersebut mempengaruhi.

Penelitian ini mengkaji pengaruh pemberian seduhan daun kelor terhadap kadar asam urat. Tabel 2 menunjukkan bahwa terdapat penurunan kadar asam urat yang signifikan pada kelompok perlakuan yang diberi seduhan daun kelor $(p<0,05)$. Daun kelor dikenal sebagai salah satu tanaman herbal untuk antioksidan ${ }^{13,14,15}$, antiinflamasi ${ }^{17}$, gout $^{33}$, $\operatorname{arthritis}^{33}$, dan lain - lain. Daun ini kaya akan vitamin dan mineral, serta beberapa senyawa fitokimia seperti alkaloid, saponin, flavonoid, fenol, tanin, dan beberapa senyawa fitokimia lain. ${ }^{7,16}$

Salah satu jenis vitamin yang terdapat pada daun kelor adalah vitamin $\mathrm{C} .{ }^{7}$ Hubungan antara vitamin $\mathrm{C}$ dengan asam urat yaitu keduanya akan mengalami reabsorpsi di tubulus proksimal. ${ }^{11}$ Vitamin C merupakan salah satu senyawa antioksidan. Oleh karena itu, vitamin $\mathrm{C}$ dapat menurunkan stres oksidatif dan inflamasi yang berpengaruh terhadap penurunan sintesis asam urat. ${ }^{4}$ Selain vitamin $\mathrm{C}$, daun kelor juga mengandung senyawa fenolik seperti flavonoid dan tanin. ${ }^{16}$

Salah satu senyawa flavonoid yaitu kuersetin ${ }^{34}$, memiliki peran menghambat aktivitas xantin oksidase, sehingga dapat menghambat pembentukan asam urat. ${ }^{9}$ Penelitian eksperimental pada tikus hiperurisemia yang diberikan senyawa kuersetin $5 \mathrm{~g} / \mathrm{kg}$ berat badan dapat menurunkan kadar asam urat secara signifikan. ${ }^{21}$ Selain melalui penghambatan aktivitas xantin oksidase, penurunan kadar asam urat dapat melalui peningkatan aktivitas urikase. Penelitian sebelumnya menunjukkan peran flavonoid dalam ekstrak rosela (Hibiscus sabdariffa $L$.) yang dapat menurunkan kadar asam urat dengan meningkatkan aktivitas urikase untuk mengubah dekomposisi asam urat dan memicu ekskresi asam urat. ${ }^{35}$ Akan tetapi dalam penelitian ini tidak dipantau aktivitas urikase subjek.

Senyawa tanin, alkaloid, dan saponin dalam daun kelor diduga memiliki peran yang hampir sama dengan flavonoid. Perannya adalah dapat menurunkan kadar asam urat dengan mengurangi aktivitas enzim xantin oksidase dalam serum dan meningkatkan konsentrasi asam urat dalam urin, serta mengikat radikal bebas selama perubahan purin menjadi asam urat. ${ }^{36,37,37}$ Hasil penelitian eksperimental pada tikus hiperurisemia yang diberikan senyawa saponin dengan dosis 60,120 , dan $240 \mathrm{mg}$ dapat menurunkan kadar asam urat secara signifikan. ${ }^{38}$
Penurunan kadar asam urat yang terjadi pada kelompok kontrol, belum diketahui penyebabnya secara pasti. Diduga karena dihentikannya pemberian otak kambing sebagai induksi. Dengan demikian, metabolisme dalam tubuh kembali normal.

\section{SIMPULAN}

Pemberian otak kambing tidak dapat meningkatkan kadar asam urat pada kedua kelompok secara signifikan. Pemberian seduhan daun kelor dapat menurunkan kadar asam urat tikus dari $2,463 \mathrm{mg} / \mathrm{dl}$ menjadi $1,788 \mathrm{mg} / \mathrm{dl}$ secara signifikan $(p=0,04)$.

\section{DAFTAR PUSTAKA}

1. Singh V, Gomez V, Swamy S. Approach to a Case of Hyperuricemia. Ind $J$ Aerospace Med. 2010;54(1):40-46.

2. So A, Thorens B. Science in medicine Uric acid transport and disease. 2010;120(6). doi:10.1172/JCI42344.dietary.

3. Hayden MR, Tyagi SC. Nutrition \& Metabolism Uric acid: A new look at an old risk marker for cardiovascular disease, metabolic syndrome, and type 2 diabetes mellitus: The urate redox shuttle. 2004;15:3-13. doi:10.1186/1743-7075-1-10.

4. Shankar A, Klein R, Klein BEK, Nieto FJ. The association between serum uric acid level and longterm incidence of hypertension : population-based $\begin{array}{lll}\text { cohort } & \text { study. } & \text { 2006:937-945. }\end{array}$ doi:10.1038/sj.jhh.1002095.

5. Oleiveira EP, Burini RC. High plasma uric acid concentration: causes and consequences. Diabetology \& Metabolic Syndrome. 2012;4(1):12. doi:10.1186/1758-5996-4-12.

6. Choi HK, Curhan G. Soft drinks, fructose consumption, and the risk of gout in men: prospective cohort study. BMJ. 2007:1-9. doi:10.1136/bmj.39449.819271.BE.

7. Witt KA. The Nutrient Content of Moringa oleifera Leaves.

8. Giancarlo A, Kyung-Jin Y, Etsuo N, Robert MR, eds. Biomarkers for Antioxidant Defense and Oxidative Damage: Principles and Practical Applications. 1st ed. USA: Blackwell; 2010:10-12.

9. Nijveldt RJ, Nood E, Hoorn DEC, Boelens PG, Norren K, Leeuwen PAM. Flavonoids : a review of probable mechanisms of action and. Am J Clin Nutr. 2001;74:418-425.

10. Choi HK, Gao X, Curhan G. Vitamin C Intake and the Risk of Gout in Men - A Prospective Study. Arch Intern Med. 2010;169(5):502-507. doi:10.1001/archinternmed.2008.606.Vitamin.

11. Gao X, Curhan G, Forman JP, Ascherio A, Choi HK. Vitamin C Intake and Serum Uric Acid Concentration in Men. $J$ Rheumatol. 2010;35(9):1853-1858. 
12. Rockwood JL, Anderson BG, Casamatta DA. Potential Uses Of Moringa Oleifera And An Examination Of Antibiotic Efficacy Conferred By M . Oleifera Seed And Leaf Extracts Using Crude Extraction Techniques Available To Underserved Indigenous Populations. International Phytothearpy of Phytotherapy Research. 2013;3(2):61-71.

13. Suphachai C. Antioxidant and anticancer activities of Moringa oleifera leaves. Journal of Medicinal Plants Research. 2014;8(7):318-325. doi:10.5897/JMPR2013.5353.

14. Singh D, Arya PV, Aggarwal VP, Gupta RS. Evaluation of Antioxidant and Hepatoprotective Activities of Moringa oleifera Lam. Leaves in Carbon Tetrachloride-Intoxicated Rats. Antioxidants. 2014;3(3):569-591. doi:10.3390/antiox3030569.

15. Luqman S, Srivastava S, Kumar R, Maurya AK, Chanda D. Experimental Assessment of Moringa oleifera Leaf and Fruit for Its Antistress, Antioxidant, and Scavenging Potential Using In Vitro and In Vivo Assays. Evidence-based complementary and alternative medicine: eCAM. 2012;2012:519084. doi:10.1155/2012/519084.

16. Oyewo EB, Adetutu A, Ayoade A, Adesokan, Akanji MA. Repeated Oral Administration of Aqueous Leaf Extract of Moringa oleifera modulated immunoactivities in Wistar Rats. Journal of Natural Sciences Research. 2013;3(6):100-109.

17. Singh GP, Garg R, Bhardwaj S, Sharma SK. AntiInflammatory Evaluation Of Leaf Extract Of Moringa Oleifera. Jornal of Pharmaceutical and Scientific Innovation. 2012;1(1):22-24.

18. Okwari OO, Alagwu EA, Dasofunjo K, Okwari KO, Obi L. Effect Of Aqueous Leaf Extract Of Moringa Oleifera On Some Renal Function Indices Of Rats. International Journal of Pharma Sciences and Research (IJPSR). 2015;6(4):777-782.

19. Halaby MS, Elmetwaly EM, Omar AAA. Effect of Moringa Oleifera on serum lipids and kidney function of hyperlipidemic rats 1. J Appl Sci Res. 2013;9(8):5189-5198.

20. Mcknight M, Allen J, Waterman JT, Hurley S, Idassi J, Minor RC. Moringa Tea Blocks Acute Lung Inflammation Induced By Swine Confinement Dust Through A Mechanism Involving Tnf-A A Expression, C-Jun N-Terminal Kinase Activation And Neutrophil Regulation. American Journal of Immunology. 2014;10(2):7387. doi:10.3844/ajisp.2014.73.87.

21. Haidari F, Rashidi MR, Eshraghian MR, Mahboob SA, Shahi MM, Keshavarz SA. Hypouricemic and antioxidant activities of Allium cepa Lilliaceae and quercetin in normal and hyperuricemic rats. Saudi Med J. 2008;29(11):1573-1579.

22. Yang RY, Lin S, Kuo G. Content and distribution of fl avonoids among 91 edible plant species. Asia Pac J Clin Nutr. 2008;17(S1):275-279.
23. Hertog MGL, Hollman PCH, Katan MB. Content of Potentialy Anticarcinogenic Flavonoids of 28 Vegetables and 9 Fruits Commonly Consumed in the Netherlands. J Agric Food CHem. 1992;40:2379-2383.

24. Pribadi FW, Ernawati DA. Efek Catechin Terhadap Kadar Asam Urat, C - Reactive Protein ( Crp ) Dan Malondialdehid Darah Tikus Putih ( Rattus norvegicus ) HIPERURISEMIA. Mandala of Health. 2010;4(1):39-46.

25. Mishra SP, Singh P, Singh S. Processing of Moringa oleifera Leaves for Human Consumption Figure: A. BullEnvPharmacolLife Sci. 2012;2(1):28-31.

26. Mitruka BM, Rawnsley HM. Clinical Biochemical and Hematological Reference Values in Normal Experimental Animals and Normal Human. 2nd ed. Masson Publishing USA, Inc; 1981:160.

27. Ellington A. Reduction Of Purine Content In Commonly Consumed Meat. 2005:33-59.

28. Katzung BG, Masters SB, Trevor AJ. Basic \& Clinical Pharmacology. 12th ed. New York: McGraw-Hill; 2012.

29. Tahir Iqmal. Arti Penting Kalibrasi pada Proses Pengukuran Analitik Aplikasi pada Penggunaan PHmeter dan Spektrofotometer Uv-Vis. 2007.

30. Nishida Y, Akaoka I, Nishizawa T. Effect of Sex Hormones on Uric Acid Metabolism in Rats. 1975;31(10):1134-1135. doi:10.1007/BF02326752.

31. Maboach SJ, Christine S, Fenny. Perbandingan Kadar Asam Urat Darah dengan Metode Spektrofotometri dan Metode Electrode-Based Biosensor.

32. Uric Acid (TBHBA). Istanbul, Turkey; 2004:1-2.

33. Sulaiman MR, Zakaria ZA, Bujarimin AS, Somchit $\mathrm{MN}$, Israf DA, Moin S. Evaluation of Moringa oleifera Aqueous Extract for Antinociceptive and Anti-Inflammatory Activities in Animal Models. Pharmaceutical Biology. 2008;46(12):838-845. doi:10.1080/13880200802366710.

34. Lim TK. Plants: Volume 3, Fruits. New York: Springer; 2012:488. doi:10.1007/9789400725348.

35. Kuo CY, Kao ES, Chan KC, Lee HJ, Huang TF, Wang CJ. Hibiscus sabdariffa L . extracts reduce serum uric acid levels in oxonate-induced rats. Journal of Functional Foods. 2012;4:375-381. doi:10.1016/j.jff.2012.01.007.

36. Hatano T, Yasuhara T, Yoshihara R, Agata I. Effect of Interaction of Tannina with Co-existing Substance. Inhibitory Effect of Tannins and Related Polyphenol of Xanthine Oxidase. 1990;38(5):12241229.

37. Tion SH, Looi CY, Hazni H, et al. Antidiabetic and antioxidant properties of alkaloids from Catharanthus roseus (L.) G. Don. Molecules (Basel, Switzerland). doi:10.3390/molecules18089770.

38. Chen GL, Wei W, Xu SY. Effect and Mechanism of Total Saponin of Discorea on Animal Experimental Hyperuricemia. Am J Chin Med. 2006;34(1):77-85. 